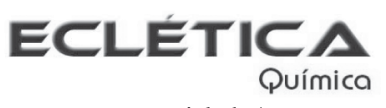

www.scielo.br/eq

Volume 30, número 1, 2005

\title{
Synthesis, characterization and thermal behaviour of solid state compounds of 4-methoxybenzoate with Manganese, Nickel and Copper.
}

\author{
E. C. Rodrigues, A. C. Vallejo, E.Y. Ionashiro, G. Bannach, M. Ionashiro \\ Departamento de Química Analítica , Instituto de Química - UNESP, Caixa Postal 355, CEP 14801-970, \\ Araraquara - SP, Brazil.
}

\begin{abstract}
Solid state M-L compounds, where M stands for bivalent $\mathrm{Mn}, \mathrm{Ni}$, $\mathrm{Cu}$ and $\mathrm{L}$ is 4-methoxybenzoate, have been synthesized. Simultaneous thermogravimetry - differential thermal analysis (TG-DTA), X-ray powder diffractometry, infrared spectroscopy, elemental analysis and complexometry were used to characterize and to study the thermal behaviour of these compounds. The results led to information about the composition, dehydration, thermal stability and thermal decomposition of the isolated compounds.
\end{abstract}

Keywords: Mn, Ni, Cu, 4-methoxybenzoate, thermal behaviour

\section{Introduction}

Several metal-ion salts of benzoic acid, as well as benzoic acid derivatives, have been reported. Wendlandt synthesized thorium salts with several organic acids, including 4-methoxybenzoic acid [1], benzoic and m-hydroxybenzoic acids [2], and studied the thermal stability and the thermal decomposition of these compounds. Glowiack and co-workers [3] studied the reaction of bivalents copper, cobalt and nickel with 3-hidroxy-4-methoxy and 3-methoxy-4-hidroxybenzoic acids. Brzyska and Karasinski [4] studied the thermal decomposition of thorium salts of benzoic and 4methoxybenzoic acids in air atmosphere. The complexation of trivalent lanthanides cations with various aromatic monocarboxylate ligands has also been described [5-7].

In this study, solid state compounds of bivalent manganese, nickel and copper with 4methoxybenzoate were prepared. These compounds were characterized and studied by complexometric titration, simultaneous TG-DTA, X-ray powder diffractometry, infrared spectroscopy and elemental analysis. The data obtained allowed us to acquire new information concerning these compounds in the solid state, including their thermal stability and thermal decomposition.

\section{Experimental}

The 4-methoxybenzoic acid (98\%) was obtained from Acros organics and used without further purification. The hydrated basic carbonates of $\mathrm{Mn}$ (II), Ni (II) and Cu (II) were prepared by adding slowly with continuous stirring, satured sodium carbonate solution to the corresponding metal chloride solutions, until complete precipitation of the metal ions; except for copper, where the sulphate was used. The precipitates were washed with distillated water until elimination of chloride or sulphate ions. (negative tests with $\mathrm{AgNO}_{3} / \mathrm{HNO}_{3}$ or $\mathrm{BaCL}_{2}$ solutions).

Solid state Mn (II), Ni (II) and Cu (II) compounds were prepared by neutralizing the corresponding aqueous suspensions of hydrated basic carbonates with 4-methoxybenzoic acid in excess. The suspensions were heated slowly up to ebullition, until total neutralization of the respective basic carbonates. The resulting solutions after cooled were maintained in an ice bath to precipitated the acid in excess. Thus, the suspensions were filtered 
through a Whatman $\mathrm{n}^{\circ} 40$ filter paper and the filtered evaporated in a water bath until near dryness and kept in a desiccator over anhydrous calcium chloride. In the solid state compounds, metal ion, water and 4-methoxybenzoate contents were determined from the TG curves. The metal ions were also determined by complexometry with standard EDTA solution $[8,9]$ after igniting the compounds of the respective oxides and their dissolution in hydrochloric acid. Carbon and hydrogen contents were determined by microanalytical procedures, with an EA 1110 CHNS-O Elemental Analyzer from CE Instruments.

$\mathrm{X}$-ray powder patterns were obtained with a SIEMENS D-5000 X-ray diffractometer using $\mathrm{Cu} \mathrm{Ka}$ radiation $(\mathrm{l}=1.544 \AA)$ and setting of $40 \mathrm{kV}$ and $20 \mathrm{~mA}$. Infrared spectra for sodium 4methoxybenzoate as well as for its metal-ion compounds, were run on a Nicolet model Impact 400 FT-IR instrument, within the $4000-400 \mathrm{~cm}^{-1}$ range.
The solid samples were pressed into $\mathrm{KBr}$ pallets.

Simultaneous TG-DTA curves were obtained with thermal analysis system model SDT 2960 from TA instruments. The purge gas was an air flow of $150 \mathrm{~mL}$ $\mathrm{min}^{-1}$. A heating rate of $10^{\circ} \mathrm{C} \mathrm{min}{ }^{-1}$ was adopted with samples weighing about $7 \mathrm{mg}$. Alumina crucible was used for TG-DTA.

\section{Results and discussion}

The analytical data are shown in Table 1. This results establish the stoichiometry of these compounds, which are in a agreement with the general formula $\mathrm{ML}_{2} \cdot \mathrm{nH}_{2} \mathrm{O}$, where $\mathrm{M}$ represents $\mathrm{Mn}$ (II), $\mathrm{Ni}$ (II) or Cu (II), $\mathrm{L}$ is 4 -methoxybenzoate and $\mathrm{n}=2,3.5$ and 3 respectively. The X-ray diffraction powder patterns (Fig.1) show that all the compounds have a crystalline structure, without evidence for formation of an isomorphous series.

Table 1. Analytical data for the $\mathrm{ML}_{2} \cdot \mathrm{nH}_{2} \mathrm{O}$ compounds

\begin{tabular}{|c|c|c|c|c|c|c|c|c|c|c|c|c|}
\hline \multirow[b]{2}{*}{ Compounds } & \multicolumn{3}{|c|}{ M (\%) } & \multicolumn{2}{|c|}{$\mathrm{L}($ lost $)(\%)$} & \multicolumn{2}{|c|}{$\mathrm{H}_{2} \mathrm{O}(\%)$} & \multicolumn{2}{|c|}{$\mathrm{C}(\%)$} & \multicolumn{2}{|c|}{$\mathrm{H}(\%)$} & \multirow{2}{*}{$\begin{array}{l}\text { Final } \\
\text { Residue }\end{array}$} \\
\hline & Calcd & EDTA & TG & Calcd & TG & Calcd & $\mathrm{TG}$ & Calcd & EA & Calcd & $\mathrm{EA}$ & \\
\hline $\mathrm{Mn}(\mathrm{L})_{2} \cdot 2 \mathrm{H}_{2} \mathrm{O}$ & 13.97 & 13.79 & 14.18 & 71.44 & 71.08 & 9.16 & 9.28 & 48.86 & 48.54 & 4.62 & 4.85 & $\mathrm{Mn}_{3} \mathrm{O}_{4}$ \\
\hline $\mathrm{Ni}(\mathrm{L})_{2} .3 .5 \mathrm{H}_{2} \mathrm{O}$ & 13.84 & 13.90 & 13.76 & 67.51 & 67.60 & 14.87 & 14.89 & 45.31 & 46.04 & 5.00 & 5.12 & $\mathrm{NiO}$ \\
\hline $\mathrm{Cu}(\mathrm{L})_{2} \cdot 3 \mathrm{H}_{2} \mathrm{O}$ & 15.13 & 14.88 & 15.21 & 68.18 & 68.08 & 12.87 & 12.99 & 45.76 & 45.52 & 4.81 & 5.02 & $\mathrm{CuO}$ \\
\hline
\end{tabular}

$\mathrm{L}=$ 4-methoxybenzoate

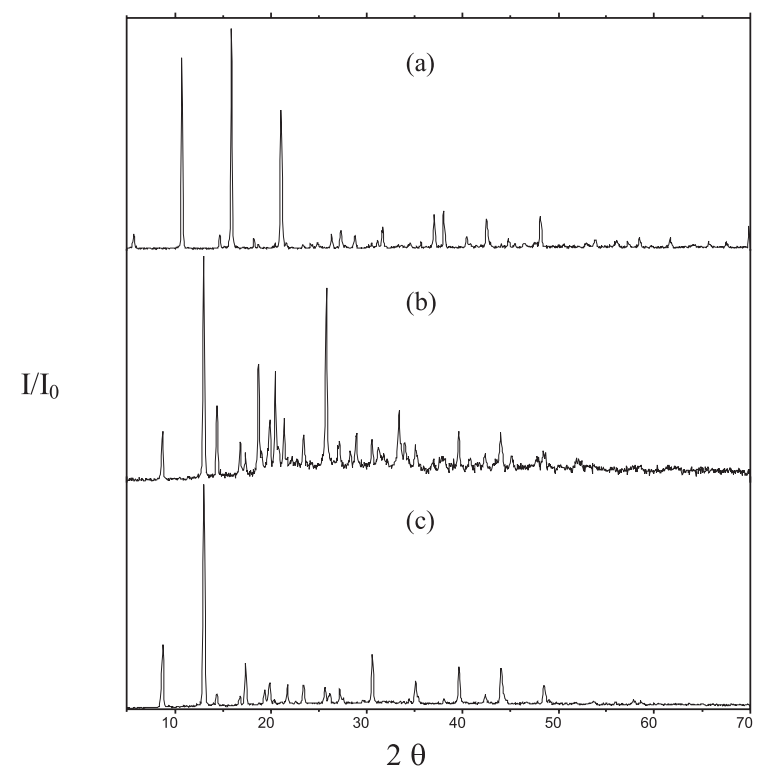

Figure 1. X-ray powder diffraction patterns of the compounds: (a) $\mathrm{Mn}(\mathrm{L})_{2} \cdot 2 \mathrm{H}_{2} \mathrm{O}$, (b) $\mathrm{Ni}(\mathrm{L})_{2} 3.5 \mathrm{H}_{2} \mathrm{O}$ and (c) $\mathrm{Cu}(\mathrm{L})_{2} \cdot 3 \mathrm{H}_{2} \mathrm{O}$. ( $\mathrm{L}=4$-methoxybenzoate). 
Infrared spectroscopic data on 4methoxybenzoate and its compounds with the metal ions considered in this work are shown in table 2 . The investigation was focused mainly within the $1700-1400 \mathrm{~cm}^{-1}$ range because this region is potentially most informative to assign coordination sites. In sodium 4methoxybenzoate, strong band at $1543 \mathrm{~cm}^{-1}$ and a medium intensity band located at $1416 \mathrm{~cm}^{-1}$ are attributed to the anti-symmetrical and symmetrical frequencies of the carboxylate groups, respectively $[10,11]$. The manganese, nickel and copper compounds, presented practically the same symmetrical and antisymmetrical vibrations of the $\mathrm{COO}^{-}$groups, and with the DN very mean when compared with the sodium salt, indicating that compounds have ionic character. The DN values also indicate a decrease of the ionic character with the increase of the atomic number of these metal ions.

Table 2. Spectroscopy data for sodium 4-methoxybenzoate and compounds with manganese, nickel and copper. ${ }^{(\mathrm{c})} ;{ }^{\mathrm{a}} \mathrm{V}$ as and $\mathrm{N}$ sym $=$ anti-symmetrical and symmetrical vibrations of the $\mathrm{COO}^{-}$group, respectively.; ${ }^{\mathrm{b}} \Delta \mathrm{v}=\mathrm{N}$ as $-\mathrm{N}$ sym; ${ }^{\mathrm{c}} \mathrm{s}=$ strong; $\mathrm{m}=$ medium

\begin{tabular}{cccc}
\hline Compound & $v$ as $\left(\mathrm{COO}^{-}\right)^{\mathrm{a}}\left(\mathrm{cm}^{-1}\right)$ & $v \operatorname{sym}\left(\mathrm{COO}^{-}\right)^{\mathrm{a}}\left(\mathrm{cm}^{-1}\right)$ & $\Delta v^{\mathrm{b}}$ \\
\hline $\mathrm{Na} \cdot 4 . \mathrm{MeO} \cdot \mathrm{Bz}$ & $1543_{\mathrm{s}}$ & $1416_{\mathrm{m}}$ & 127 \\
$\mathrm{Mn}(4 . \mathrm{MeO} \cdot \mathrm{Bz})_{2}$ & $1533_{\mathrm{s}}$ & $1408_{\mathrm{m}}$ & 125 \\
$\mathrm{Ni}(4 . \mathrm{MeO} \cdot \mathrm{Bz})_{2}$ & $1547_{\mathrm{s}}$ & $1439_{\mathrm{m}}$ & 108 \\
$\mathrm{Cu}(4 . \mathrm{MeO} \cdot \mathrm{Bz})_{2}$ & $1531_{\mathrm{s}}$ & $1435_{\mathrm{m}}$ & 96 \\
\hline
\end{tabular}

Simultaneous TG-DTA curves of the compounds are shown in Figs. 2 - 4. These curves show mass losses in steps, corresponding to endothermic peaks due to dehydration and the exothermic peaks attributed to oxidation of the organic matter. In all the TG-DTA curves, the final mass loss profile shows that the sample temperature is greater than the oven temperature, indicating that the oxidation of the organic matter is accompanied by the combustion.

The thermal stability of the anhydrous compounds (I), as well the final temperature of thermal decomposition (II) as shown by the TGDTA curves, depend on the nature of the metal ion, and they follow the order:

$$
\begin{aligned}
& \text { (I) } \quad \mathrm{Mn}>\mathrm{Cu}>\mathrm{Ni} \\
& \text { (II) } \mathrm{Mn}>\mathrm{Ni}>\mathrm{Cu}
\end{aligned}
$$

The thermal behaviour of the compounds is heavily dependent on the nature of the metal ion and so the features of each these compounds are discussed individually.

Manganese compound. The simultaneous TG-DTA curves are shown in Fig. 2. The first mass loss observed between 80 and $150^{\circ} \mathrm{C}$, corresponding to an endothermic peak at $139^{\circ} \mathrm{C}$ is due to dehydration with loss of $2 \mathrm{H}_{2} \mathrm{O}$ (Calcd = 9.16\%; TG = 9,28\%). The thermal decomposition of the anhydrous compound occurs in two overlapping steps between $240-390^{\circ} \mathrm{C}$, and 390 and $456^{\circ} \mathrm{C}$, with losses of 32.70 and $38.38 \%$, respectively, corresponding to the exothermic peak at $456^{\circ} \mathrm{C}$, attributed to oxidation and combustion of the organic matter. The total mass loss up to $456^{\circ} \mathrm{C}$, is in agreement with the formation of $\mathrm{Mn}_{3} \mathrm{O}_{4}$ as final residue $($ calcd. $=80.60 \%$, TG. $=80.36 \%$ ) and confirmed by X-ray powder diffractometry. 


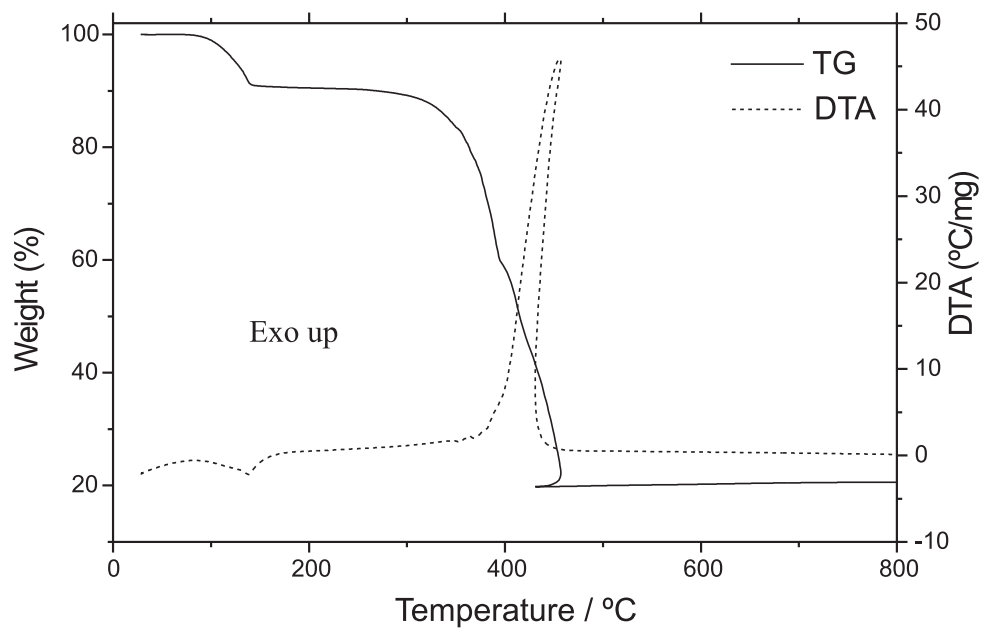

Figure 2. TG and DTA curves of the $\mathrm{Mn}(\mathrm{L})_{2}$. $2 \mathrm{H}_{2} \mathrm{O}$ ( $\mathrm{L}=4$-methoxybenzoate).

Nickel compound. The TG-DTA curves are shown in Fig. 3. The mass loss that occurs between 100 and $160^{\circ} \mathrm{C}$, corresponding to the endothermic peak at $143^{\circ} \mathrm{C}$, is due to dehydration with loss of $3.5 \mathrm{H}_{2} \mathrm{O}$ (Calcd. $=14.87 \%$; $\mathrm{TG}=14.89 \%$ ). Immediately after the dehydration, the anhydrous compound shows mass loss that begins with a slow process (up to $320^{\circ} \mathrm{C}$ ), followed by a fast process to give the oxide level beginning at $430^{\circ} \mathrm{C}$, with losses of 5.60 and $62.00 \%$, respectively, corresponding to the exothermic event with two peaks at 410 and $415{ }^{\circ} \mathrm{C}$, attributed to the oxidation and combustion of the organic matter. In both temperatures (410 and $415^{\circ} \mathrm{C}$ ), the anomaly observed in the TG-DTA curves is due to the combustion of the organic matter, where the sample temperature exceed the oven one. The total mass loss up to $430^{\circ} \mathrm{C}$, is in agreement with the formation of $\mathrm{NiO}$ as final residue (Calcd. $=82.38 \%$; $\mathrm{TG}=82.49 \%$ ) and confirmed by $\mathrm{X}$-ray powder diffractometry.

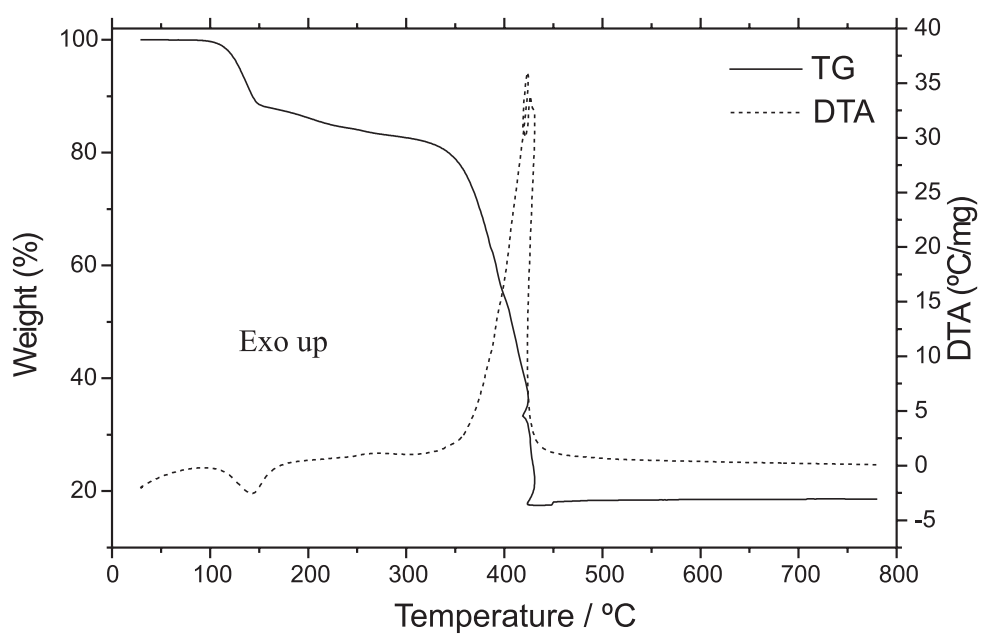

Figure 3. TG and DTA curves of the $\mathrm{Ni}(\mathrm{L})_{2} 3.5 \mathrm{H}_{2} \mathrm{O}$ (L=4-methoxybenzoate). 
Copper compound. The TG-DTA curves are shown in Fig.4. The first mass loss observed between 70 and $120^{\circ} \mathrm{C}$, corresponding to the endothermic peak is due to dehydration water with loss of $3 \mathrm{H}_{2} \mathrm{O}$ (Calcd. 12.87\%; TG = 12.99\%) the anhydrous compounds is stable up to $235^{\circ} \mathrm{C}$, and above this temperature the thermal decomposition occurs in three overlapping steps with losses of $14.50 \%\left(235-262^{\circ} \mathrm{C}\right), 21.76 \%$ (262- $\left.350^{\circ} \mathrm{C}\right)$ and $31.82 \%\left(350-415^{\circ} \mathrm{C}\right)$, corresponding to exothermic peaks at $278^{\circ} \mathrm{C}, 319^{\circ} \mathrm{C}$ and $415^{\circ} \mathrm{C}$, respectively, attributed to the oxidation and for the last step, oxidation and combustion of the organic matter. The total mass loss up to $415^{\circ} \mathrm{C}$ is in agreement with the formation of $\mathrm{CuO}$, as final residue $($ Calcd $=81.05 \%$; $\mathrm{TG}=81.07 \%)$, and confirmed by X-ray powder diffractometry.

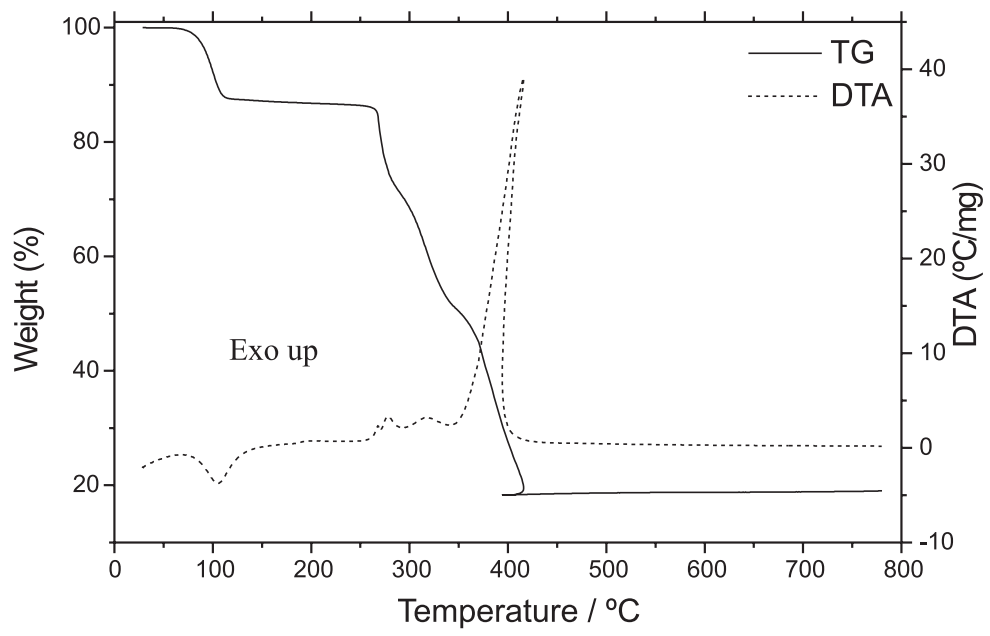

Figure 4. TG and DTA curves of the $\mathrm{Cu}(\mathrm{L})_{2}$. $3 \mathrm{H}_{2} \mathrm{O}(\mathrm{L}=4$-methoxybenzoate).

\section{Conclusions}

From TG, complexometry and elemental analysis data, a general formula could be established for the binary compounds involving $\mathrm{Mn}$ (II), $\mathrm{Ni}$ (II) and $\mathrm{Cu}$ (II), and 4-methoxybenzoate.

The X-ray powder patterns pointed out that the synthesized compounds have a crystalline structure without evidence concerning the formation of isomorphous series.

The infrared spectroscopy data suggest that the 4-methoxybenzoate of manganese, nickel and copper are compound of ionic nature.
The TG-DTA, provided previously unreported information about the thermal stability and thermal decomposition of these compounds.

\section{Acknowledgements}

The authors thank FAPESP (Proc. 97/126468), CNPq and CAPES foundations (Brazil) for financial support.

Recebido em: 11/05/2004

Aceito em: 19/11/2004 
E. C. Rodrigues, A. C. Vallejo, E. Y. Ionashiro, G. Banach, M. Ionashiro. Síntese, caracterização e comportamento térmico dos 4-metoxibenzoatos de manganês, níquel e cobre, no estado sólido.

Resumo: Compostos M - L foram sintetizados no estado sólido, onde M representa os íons bivalentes Mn, $\mathrm{Ni}$, Cu e L é o ânion 4 - metoxibenzoato. Esses compostos foram caracterizados e estudados, utilizando-se as técnicas de difração de raios x pelo método do pó, espectroscopia na região do infravermelho, análise elementar, complexometria e termogravimetria - análise térmica diferencial simultânea (TG - DTA). Os resultados permitiram obter informações com respeito à estequiometria, desidratação, estabilidade térmica e decomposição térmica.

Palavras-chave: Mn, $\mathrm{Ni}, \mathrm{Cu}, 4$ - metoxibenzoato, comportamento térmico.

\section{References}

[1] W. W. Wendlandt. Anal. Chim. Acta. 17(3) (1957) 295.

[2] W. W. Wendlandt. Anal. Chem. 29(5) (1957) 800.

[3] T. Glowiak, H. Kozlowski, L. S. Erre, B. Gulinati, G. Micera, A. Pozzi, S. Bruni, Journal Coordination Chemistry. 25(1) (1992) 75.

[4] W. Brzyska, S. Karasinski, Journal Thermal Analysis. 39(4) (1993) 429.

[5] S. S. Yun, S. H. Bae, S. W. Hong, S. K. Kang. I. H. Kim, J. T. Park, Thermochimica Acta. 246(1) (1994) 39.

[6] O. S. Siqueira, C. B. Melios, M. Ionashiro, M. de Moraes, M. Molina, J. Alloys Compd. 225 (1) (1995) 267.
[7] S. J. Yun, S. K. Kang, S. S. Yun, Thermochim Acta. 331(1) (1999) 13.

[8] H. A. Flaschka, EDTA Titrations, Pergamon Press, Oxford, 1964.

[9] C. N. Oliveira, M. Ionashiro, C. A. F. Graner, Ecl. Quim. 10 (1985) 7.

[10] G. Socrates, Infrared Characteristic Group Frequencies, Wiley, New York, 2nd edn., 1994.

[11] R. M. Silverstein, F. X. Webster, Identificação espectrométrica de compostos orgânicos. LTC - Livros Técnicos e Científicos Editora S. A, Rio de Janeiro, 6th edn., 2000. 